\title{
PENGARUH TERAPI AKUPUNKTUR TERHADAP PENURUNAN TEKANAN DARAH PADA LANSIA DENGAN HIPERTENSI DI PANTI WERDHA MOJOPAHIT MOJOKERTO
}

\author{
Sufendi Hariyanto* \\ Fakultas Ilmu Kesehatan Unipdu Jombang \\ Tromol Pos X Rejoso Peterongan Jombang, Jawa Timur Kode Pos:61481 \\ sufendihariyanto@fik.unipdu.ac.id
}

\begin{abstract}
ABSTRAK
Hipertensi merupakan masalah kesehatan yang banyak ditemukan pada orang lanjut usia. Faktor kebiasaan hidup yang sering menyebabkan timbulnya hipertensi salah satunya adalah adanya ketegangan psikologis atau sress, dalam penangan hipertensi dapat dilakukan dengan pengobatan non farmakologi seperti terapi akupunktur. Penelitian ini bertujuan untuk mengetahui adanya pengaruh terapi akupunktur terhadap penurunan tekanan darah pada lansia dengan hipertensi di Panti Werdha Mojopahit Mojokerto. Penelitian menggunakan Metode Quasy-experimental dengan desain pretest-posttest control group desain, dengan jumlah sampel sebanyak 16 responden ( 8 kelompok perlakuan dan 8 kelompok kontrol) dengan mengunakan teknik purposive sampling. Pengumpulan data dilakukan dengan metode obsevasi dan selanjutnya ditabulasi dengan menggunakan distribusi frekuensi dan diuji menggunakan uji T-Test Independen dan Paired $T$ Test tingkat kemaknaan $\alpha=0,05$. Dari hasil penelitian ini menunjukan antara kedua kelompok dihasilkan hipertensi pada lansia, setelah diberikan terapi akupunktur sebanyak 4 kali dalam waktu 4 hari sekali terdapat penurunan tekanan darah yang signifikan pada kelomok perlakuan dibanding kelompok kontrol baik tekanan sistolik maupun diastolik pada uji Paired T- Test. Kesimpulan yang dapat diambil dari penelitian ini adalah ada pengaruh terapi akupunktur terhadap penurunan tekanan darah pada lansia dengan hipertensi. Dari hasil yang ada tersebut terapi akupunktur dapat direkomendasikan untuk mengatasi masalah hipertensi pada lansia yang di sebabkan oleh konsumsi garam yang tinggi, obesitas, kurang olahraga, stress, merokok, kafein dan faktor genetik.
\end{abstract}

\section{Kata kunci: terapi akupunktur, hipertensi, lansia}

\begin{abstract}
Hypertension is a health problem that commonly found in elderly. Habit factors that often cause hypertension, such as psychological tension or sress. One of the hypertension treatment in nonpharmacological with acupuncture therapy. This study aimed to investigate the effect of acupuncture therapy on blood pressure in elderly with hypertension diagnosist in Panti Werdha Mojopahit, Mojokerto, East Java, Indonesia. Research method used Quasi Experimental pretestposttest control group design. Total sample 16 respondents ( 8 respondents in treatment groups and 8 respondents in control group) with purposive random sampling technique. Data was collected by observation method, then tabulated using frequency distributions and analized with T-test and Paired Independent T-Test significance level $\alpha=0.05$. Result shows between the two groups generated hypertension toward elderly, after acupuncture therapy in 4 times (in 4 days) there was a significant decrease of blood pressure. The control group, both systolic and diastolic pressure in the Paired T-Test. The conclusion, there was no negative side effect of acupuncture therapy on blood pressure toward elderly with hypertension diagnosist. Acupuncture therapy recomended for
\end{abstract}


hypertension in the elderly with problem of a high salt intake, obesity, lack of exercise, stress, smoking, caffeine and genetic factors.

Keywords: acupuncture therapy, hypertension, elderly 


\section{PENDAHULUAN}

Tekanan Darah Tinggi (hipertensi) adalah keadaan yang ditandai dengan terjadinya peningkatan tekanan darah di dalam arteri. Hipertensi merupakan penyakit yang umumnya tidak menunjukan gejala, atau apabila ada, gejalanya tidak jelas, sehingga tekanan yang tinggi di dalam arteri sering tidak dirasakan oleh penderita. Tekanan darah biasanya meningkat seiring dengan bertambahnya usia seseorang dan paling banyak ditemukan pada mereka yang berusia di atas 40 tahun ${ }^{1}$.

Hipertensi pada lansia merupakan masalah kesehatan yang banyak ditemui pada orang lanjut usia. Berdasarkan laporan PBB, the sex age distribution on population- the 1990 revision population studies, united nationas, new York, 1991 yang di kutip oleh Setyabudi (2005) menyatakan bahwa jumlah penduduk lansia meningkat dengan cepat diperkirakan pada tahun 2020 jumlah lansia mencapai 11,4\% dari jumlah penduduk Indonesia. Penelitian epidemiologi yang dilakukan di Indonesia menunjukan $1,8-28,6 \%$ penduduk yang berusia diatas 20 tahun terjadi peningkatan resiko hipertensi. Sedangkan dari hasil studi morbiditas dan disabilitas SKRT (2001) menunjukan bahwa sebanyak $43 \%$ penyakit yang diderita oleh lansia di Indonesia adalah hipertensi dan $75 \%$ di antaranya diderita oleh mereka yang berusia diatas 65 tahun. Berdasarkan hasil studi pendahuluan di Panti Werda Mojokerto, pada tahun 2015 jumlah lansia di panti werda mojokerto sebanyak 41 lansia dan ditemukan 19 lansia yang menderita hipertensi.

Hipertensi pada lansia disebabkan oleh banyak faktor yang erat kaitannya dengan proses menua (aging proses). Faktor keturunan, ciri perseorangan, dan gaya hidup ${ }^{2}$. Faktor kebiasaan hidup yang sering menyebabkan timbulnya hipertensi salah satunya adalah adanya ketegangan psikologis atau stress ${ }^{3}$. Sudah lama diketahui bahwa tekanan-tekanan psikologis seperti stress, rasa takut dan marah, dapat meningkatkan tekanan darah, ketika terjadi ketegangan akibat dari stress akan meningkatkan hiperaktivitas dari system saraf simpatif sehingga hormone stres seperti kortisol dan katekolamin dalam darah menjadi ,meningkat. Peningkatan hormon ini menyebabkan terjadi vasikontriksi atau penyempitan pada pembuluh darah sehingga tekanan darah menjadi meningkat ${ }^{4}$.

Penanganan hipertensi dapat dilakukan dengan dua cara yaitu dengan cara pengobatan farmakologi dan nonfarmakologi. Pengobatan farmakologi salah satunya adalah Beta-bloker yang dapat memperlambat kerja jantung dan memperlebar pembuluh darah ${ }^{5}$. Selain dengan pengobatan farmakologi, bisa juga dibantu dengan pengobatan nonfarmakologi seperti terapi akupunktur, pengobatan dengan cara perangsangan pada permukaan tubuh yang mampu menghilangkan atau mengurangi gejala penyakit, meregulasi gangguan fungsi tubuh, memperbaiki keadaan patologik, mempertinggi kualitas hidup, meningkatkan estetika (kecantikan), mencegah timbulnya penyakit ${ }^{6}$.

Akupunktur dikenal sebagai salah satu sistem pengobatan Cina yang menggunakan metode penusukan jarum pada titik-titik tertentu untuk menyembuhkan penyakit atau mencapai kondisi kesehatan tertentu 7. Peningkatan pada titik akupunktur diduga memberikan rangsangan pada saraf otonom yang menimbulkan hambatan rangsangan simpatis, sehingga terjadi hambatan pada saraf vasokonstriktor yang berakibat vasodilatasi. Penusukan pada titik taichong (LV 3) menyebabkan penurunan tekanan darah disertai penurunan plasma angiotensin II. Hal ini menunjukkan bahwa sistem renin angiotensin memegang peranan penting dalam penurunan tekanan darah dengan akupunktur ${ }^{8}$.

Berdasarkan dari uraian di atas peneliti tertarik ingin melakukan penelitian apakah ada pengaruh terapi akupunktur terhadap perubahan tekanan darah pada lansia dengan hipertensi di Panti Werdha Mojopahit Mojokerto.

BAHAN DAN METODE 
Dalam penelitian ini, peneliti menggunakan penelitian Quasy Experiment dengan desain Pretest - Postest Control Group Desingn, yaitu jenis penelitian yang dilakukan untuk mengungkapkan hubungan sebab akibat dengan cara melibatkan kelompok kontrol disamping kelompok eksperimental. Dalam rancangan ini, kelompok eksperimental diberi perlakuan sedangkan kontrol tidak. Pada kedua kelompok diawali dengan pretest, dan setelah penberian perlakuan diadakan pengukuran kembali atau pasca test ${ }^{9}$. Dalam Penelitian ini, populasinya adalah seluruh lansia yang mengalami hipertensi di Panti Werdha Mojopahit Mojokerto. Jumlah sampel sebanyak 18 orang lansia hipertensi di Panti Werdha Mojopahit Mojokerto dengan dibagi menjadi dua kelompok, 8 orang kelompok perlakuan dan 8 orang menjadi kelompok kontrol yang memenuhi kriteria. Kriteria pada penelitian pasien hipertensi dengan terapi obat antihipertensi tekanan darah sistolik > 140 dan atau diastolik > $90 \mathrm{mmHg}$ yang sanggup menjadi responden di Panti Werdha "Mojopahit" Mojokerto. Penelitian ini menggunakan teknik Non Probability Sampling dengan metode sampling Purposive Sampling.

\section{HASIL PENELITIAN}

1. Tekanan darah pada lansia sebelum dilakukan terapi akupunktur

Tabel 1. Tekanan Darah sebelum dilakukan terapi Akupunktur pada lansia di Panti Werdha Mojopahit Mojokerto

\begin{tabular}{|c|c|c|c|}
\hline Keterangan & Hasil & $\begin{array}{l}\text { Kelompok } \\
\text { Kontrol }\end{array}$ & $\begin{array}{l}\text { Kelompok } \\
\text { Perlakuan }\end{array}$ \\
\hline \multirow{3}{*}{$\begin{array}{l}\text { Tekanan Darah } \\
\text { Sistol sebelum } \\
\text { dilakukan terapi } \\
\text { Akupunktur }\end{array}$} & $\begin{array}{l}\text { Rata-rata } \\
\text { (Mean) }\end{array}$ & 170,00 & 172,50 \\
\hline & $\begin{array}{l}\text { Std. } \\
\text { Deviation }\end{array}$ & 9,258 & 16,690 \\
\hline & $\mathrm{N}$ & 8 & 8 \\
\hline \multirow{3}{*}{$\begin{array}{l}\text { Tekanan Darah } \\
\text { Diastol sebelum } \\
\text { dilakukan terapi } \\
\text { Akupunktur }\end{array}$} & $\begin{array}{l}\text { Rata-rata } \\
\text { (Mean) }\end{array}$ & 106,25 & 107,5 \\
\hline & $\begin{array}{l}\text { Std. } \\
\text { Deviation }\end{array}$ & 7,44 & 7,071 \\
\hline & $\mathrm{N}$ & 8 & 8 \\
\hline
\end{tabular}

Pada tabel 1 bahwa pada kelompok kontrol sebelum diberikan terapi akupunktur diperoleh nilai rata-rata hasil tekanan darah sistolik 170,00 mmHg dengan Std. Deviation 9,258. Pada kelompok perlakuan nilai rata-rata hasil tekanan darah sistolik $172,50 \mathrm{mmHg}$ dengan Std. Deviation 16,690 sedangkan pada tekanan diastole nilai rata-rata hasil tekanan darah pada kelompok kontrol 106,25 mmHg dengan Std. Deviation 7,44 dan pada kelompok perlakuan nilai rata-rata tekanan darah diastole 107,50 mmHg dengan Std. Deviation 7,071 hal ini dapat di artikan bahwa pada kelompok control dan kelompok perlakuan rata-rata tekanan darah sistolik sebelum dilakukan terapi jus mentimun. Sesuai dengan kriteria menurut WHO bahwa tekanan darah sistol 160-179 mmHg dan tekanan darah diastole 100-109 $\mathrm{mmHg}$ termasuk kategori hipertensi sedang.

2. Tekanan darah pada lansia setelah dilakukan terapi akupunktur.

Tabel 2 Tekanan Darah setelah dilakukan terapi Akupunktur pada lansia di Panti Werdha Mojopahit Mojokerto

\begin{tabular}{|c|c|c|c|}
\hline Keterangan & Hasil & $\begin{array}{l}\text { Kelompo } \\
\text { k Kontrol }\end{array}$ & $\begin{array}{l}\text { Kelompo } \\
\mathrm{k} \\
\text { Perlakuan }\end{array}$ \\
\hline \multirow{3}{*}{$\begin{array}{l}\text { Tekanan } \\
\text { Darah Sistol } \\
\text { setelah } \\
\text { dilakukan } \\
\text { terapi } \\
\text { Akupunktur }\end{array}$} & $\begin{array}{l}\text { Rata-rata } \\
\text { (Mean) }\end{array}$ & 163,75 & 150,00 \\
\hline & $\begin{array}{l}\text { Std. } \\
\text { Deviation }\end{array}$ & 11,877 & 16,903 \\
\hline & $\mathrm{N}$ & 8 & 8 \\
\hline \multirow{3}{*}{$\begin{array}{l}\text { Tekanan } \\
\text { Darah Diastol } \\
\text { setelah } \\
\text { dilakukan } \\
\text { terapi } \\
\text { Akupunktur }\end{array}$} & $\begin{array}{l}\text { Rata-rata } \\
\text { (Mean) }\end{array}$ & 101,25 & 90 \\
\hline & $\begin{array}{l}\text { Std. } \\
\text { Deviation }\end{array}$ & 8,345 & 5,345 \\
\hline & $\mathrm{N}$ & 8 & 8 \\
\hline
\end{tabular}

Pada tabel 5.2 bahwa pada kelompok kontrol sesudah diberikan terapi akupunktur diperoleh nilai rata-rata hasil tekanan darah sistolik 163,75 mmHg dengan Std. Deviation 11,877 pada kelompok perlakuan nilai rata-rata hasil tekanan darah sistolik 150,00 $\mathrm{mmHg}$ dengan Std. Deviation 16,903 sedangkan pada tekanan 
diastole nilai rata-rata hasil tekanan darah pada kelompok kontrol 101,25 mmHg dengan Std. Deviation 8,345 dan pada kelompok perlakuan nilai rata-rata tekanan darah diastole 90,00 mmHg dengan Std. Deviation 5,345 Hal ini dapat diartikan bahwa pada kelompok perlakuan mengalami penurunan rata-rata tekanan darah sistolik maupun diastolic yang signifikan daripada pada kelompok kontrol yang dilakukan terapi akupunktur selama 16 hari.

\section{Analisa Pengaruh Terapi Akupunktur} terhadap penurunan tekanan darah pada lansia dengan hipertensi.

Tabel 3. Tabel Analisa Pengaruh Terapi Akupunktur terhadap penurunan tekanan darah pada lansia dengan Hipertensi dipanti Werdha Mojopahit Mojokerto.

\begin{tabular}{|c|c|c|c|c|c|c|c|}
\hline \multirow{3}{*}{ Ket. } & \multirow{3}{*}{ Hasil } & \multicolumn{4}{|c|}{ T Sampel Becrparsagan (Paired) } & \multicolumn{2}{|c|}{ Independent $\mathrm{t}$ Test } \\
\hline & & \multicolumn{2}{|c|}{ Peclakuan, } & \multicolumn{2}{|c|}{ Kontrol } & \multirow{2}{*}{\begin{tabular}{|l|} 
Perclakuan \\
Post
\end{tabular}} & \multirow{2}{*}{$\begin{array}{l}\text { Kontrol } \\
\text { Post }\end{array}$} \\
\hline & & Pre & Post & Pre & Post & & \\
\hline \multirow{4}{*}{$\begin{array}{l}\text { Takanan } \\
\text { Darah } \\
\text { Sistols }\end{array}$} & Rata-rata & 172,50 & 150,00 & 170,00 & 163,75 & 150,00 & 163,75 \\
\hline & Std. Derisasi & 16,690 & 16,903 & 9,258 & 11,877 & 16,903 & 11,877 \\
\hline & $\begin{array}{l}\text { Rata-rata } \\
\text { perbeddagn }\end{array}$ & \multicolumn{2}{|l|}{22,5} & \multicolumn{2}{|l|}{6,25} & & \\
\hline & Signifikansti & $\begin{array}{l}p= \\
0,000\end{array}$ & $\begin{array}{l}\mathrm{t}= \\
6,148\end{array}$ & $\begin{array}{l}p= \\
0,095\end{array}$ & $\begin{array}{l}\mathrm{t}= \\
1,930\end{array}$ & $\begin{array}{l}p \\
0,111\end{array}$ & $\mathrm{t}=-1,823$ \\
\hline \multirow{4}{*}{$\begin{array}{l}\text { Telkanan } \\
\text { Darah } \\
\text { Diastole }\end{array}$} & Rata-rata & 107,50 & 90,00 & 106,25 & 101,25 & 90,00 & 101,25 \\
\hline & Std. Dexiassi & 7,071 & 5,345 & 7,440 & 8,345 & 5,345 & 8,345 \\
\hline & $\begin{array}{l}\text { Rata-rata } \\
\text { perbedidasm }\end{array}$ & \multicolumn{2}{|l|}{17,5} & \multicolumn{2}{|l|}{5} & & \\
\hline & Signifikgansi & $p_{0,000}^{p}=$ & $\begin{array}{l}\mathrm{t}= \\
10,6993\end{array}$ & $\begin{array}{l}p= \\
0,104\end{array}$ & $\begin{array}{l}\mathrm{t}= \\
1,871\end{array}$ & $p_{0,026}^{p}=$ & $\mathrm{t}=-2,826$ \\
\hline
\end{tabular}

Secara praktis dapat dilihat pada tabel diatas bahwa sebelum dan sesudah dilakukan terapi akupunktur pada kelompok perlakuan didapatkan nilai rata-rata perbedaan hasil pengukuran tekanan darah sistol 22,5 yang lebih besar daripada kelompok kontrol yang hanya didapat nilai 6,25 . Nilai rata-rata perbedaan hasil pengukuran tekanan darah diastole 17,5 yang lebih besar dari pada kelompok kontrol yang hanya didapat nilai ratarata perbedaan hasil pengukuran tekanan darah diastole 5. Artinya ada perubahan hasil pengukuran tekanan darah sistol dan hasil pengukuran tekanan diastole pada lansia dengan hipertensi setelah dilakukan terapi akupunktur.

Hasil penelitian ini dapat diperkuat dengan hasil pengujian statistik lain yang berfungsi untuk mengetahui perbedaan hasil pengukuran tekanan darah sistol dan diastole antara kelompok perlakuan dan kelompok kontrol yaitu dengan menggunakan Uji Independent $t$ Test. Setelah dilakukan uji statistik independent $t$ Test pada kelompok perlakuan dan kelompok control dengan membandingkan pengukuran darah siastol dan pengukuran darah diastole diperoleh hasil $\mathrm{p}=$ 0,000 dan pada pengukuran darah diastole diperoleh hasil $\mathrm{p}=0,000$. Setelah diberikan perlakuan $\mathrm{p}<0,05$, sehingga dapat disimpulkan bahwa Ho ditolak, yang artinya ada penurunan tekanan darah pada lansia dengan Hipertensi setelah dilakukan terapi akupunktur di Panti Werdha Mojopahit Mojokerto.

\section{PEMBAHASAN}

Analisis tekanan darah pada lansia sebelum dilakukan terapi akupunktur Pada tabel 1 Ada beberapa faktor kemungkinan penyebab terjadi peningkatan tekanan darah pada lansia di Panti Werdha Mojopahit Mojokerto. Diantaranya adalah karena faktor genetis, perubahan-perubahan secara biologis yang terjadi karena proses menua, (aging proses) dan gaya hidup yang kurang sehat ${ }^{10}$.

Dari faktor segi genetis peneliti tidak mengkaji apakah ada riwayat hipertensi pada keluarga sampel. Dikarenakan rata-rata lansia banyak yang tidak mengetahui penyakit yang pernah diderita keluarga sebelumnya, sedangkan perubahan-perubahan secara biologis yang mungkin berperan pada 
terjadinya peningkatan tekanan darah pada lansia adalah perubahan curah jantung ${ }^{11}$. Tahanan perifer yang meningkat, aliran darah ginjal dan laju filtrasi glomerulus yang menurun, penurunan sensitifitas barireseptor, aktifitas syaraf simpatis yang meningkat ${ }^{12}$.

Hasil penelitian orang lain ternyata nilai rata-rata tekanan darah sistolik dan diastolic sebelum dilakukan terapi akupunktur cukup tinggi. Sesuai dengan criteria menurut WHO bahwa tekanan darah $169 \mathrm{mmHg}$ termasuk dalam kategori tekanan darah sedang ${ }^{13}$, dan pada hasil yang dilakukan peneliti nilai rata-rata tekanan darah sebelum dilakukan terapi akupunktur termasuk dalam kategori sedang.

Analisis tekanan darah pada lansia setelah dilakukan terapi akupunktur

Berdasarkan tabel 2 diatas hasil pengukuran tekanan darah pada kelompok perlakuan yang telah dilakukan terapi akupunktur di dapatkan data bahwa nilai rata-rata tekanan sistolik dan diastolik mengalami penurunan yang signifikan, sedangkan pada kelompok kontrol mengalami penurunan namun tidak se signifikan yang dilakukan terapi akupunktur yang telah dilakukan peneliti selama 4 kali pemberian terapi dengan waktu 4 hari sekali.

Analisis Pengaruh Terapi Akupunktur terhadap Penurunan Tekanan Darah pada Lansia dengan Hipertensi

Hasil penelitian ini diperkuat dengan hasil pengujian statistic yang lain yang berfungsi untuk mengetahui adakah perbedaan hasil pengukuran tekanan darah sistol dan diastole antara kelompok perlakuan dan kelompok kontrol yaitu dengan menggunakan uji independent $t$ Test. Setelah dilakukan uji statistik independen $t$ Test pada post kelompok kontrol dan kelompok perlakuan dengan membandingkan pengukuran tekanan darah diastol diperoleh hasil $\mathrm{p}=0,026(\mathrm{p}<0,05)$ sehingga dapat disimpulkan bahwa Ho ditolak yang artinya ada pengaruh terapi akupunktur terhadap penurunan tekanan darah pada lansia dengan hipertensi di Panti Werdha Mojopahit Mojokerto. Sedangkan pada post kelompok perlakuan dan kelompok kontrol pada hasil pengukuran tekanan sistol didapatkan hasil $\mathrm{p}=$ $0,111$ ( $\mathrm{p}>0,05)$ yang artinya bahwa Ho diterima yang berarti tidak ada pengaruh terapi akupunktur terhadap penurunan tekanan darah pada lansia dengan hipertensi.

Terapi akupunktur pada sidrom Hiperaktifitas Yang dengan defisiensi Yin ini lebih terlihat pada pengaruh tekanan darah diastol. Sedangkan pada tekanan sistol tidak terdapat penurunan yang signifikan uji statistik, hal ini dapat diartikan bahwa dalam melakukan terapi akupunktur pada sindrom Hiperaktifitas Yang dengan defisiensi Yin lebih berpengaruh terhadap penurunan tekanan diasto ${ }^{14}$.

Untuk mendapatkan hasil terapi yang maksimal dalam menangani kasus-kasus akupunktur seperti hipertensi seorang akupunkturis dituntut untuk melakukan terapi akupunktur secara professional. $^{15}$ Sesuai dengan prosedur yang sudah ditentukan dimulai dari 4 cara pemeriksaan akupunktur meliputi wang (pengamatan), wen (auskultasi/oksitasi), wun (anamnesa), dan cie (palpasi) dan 8 dasar diagnosa ( meliputi Yin, Yang, Luar, Dalam, Dingin, Panas, Ekses, Defisien). Dengan pemeriksaan yang tepat dan sistematis maka diagnosis dapat ditegakkan dengan benar sehingga program penanganan atau terapi yang diberikan benar-banar berdasarkan permasalahan pasien. Selanjutnya bila menemukan kasus akupunktur yang berat maka dapat melakukan tindakan terapi yang lebih baik.

\section{SIMPULAN DAN SARAN Simpulan}

Tekanan darah pada lansia setelah dilakukan penelitian di dapatkan data bahwa nilai rata-rata tekanan sistolik maupun diastolik mengalami penurunan yang signifikan. Sedangkan pada kelompok kontrol mengalami penurunan rata-rata pada tekanan sistolik maupun diastolik namun tidak se signifikan pada kelompok perlakuan yang telah diberikan terapi akupunktur 4 hari sekali selama 4 kali 
pemberian terapi pada lansia dengan hipertensi di Panti Werdha Mojopahit Mojokerto.

\section{Saran}

\section{Bagi Penderita Hipertensi}

Perlu adanya kontrol dan terapi akupunktur yang teratur sebagai upaya preventif mengiggat penyakit ini sering muncul tanpa adanya tanda dan gejala yang tampak dan menghindari adanya komplikasi yang berkelanjutan.

\section{Institusi Panti Werdha Mojopahit Mojokerto}

${ }^{1}$ Junaidi, Iskandar. 2010. Hipertensi. Jakarta: Bhuana Almu Popular.

2 Gunawan. 2001. Hipertensi : Tekanan DarahTinggi. Yogyakarta: Kanisius.

${ }^{3}$ Dalimartha, Setiawan dkk 2008. Care Your Self Hipertensi. Jakarta: Penerbit KDT.

${ }^{4}$ Smeltzer \& Bare. 2002. Keperawatan Medikal Bedah. Edisi 8 Vol 3. Jakarta: EGC

${ }^{5}$ Maryam, Siti R. 2008. Mengenal Usia Lanjut dan Perawatannya. Jakarta: Salemba Medika.

${ }^{6}$ Sudirman, Syarif. 2010. Efek Samping Terapi Akupunktur.

7 Alamsyah, Isa. 2010. Cara lebih mudah menemukan titik terapi acupoint. Depok: AsmaNadia Publishing House.

8 Agnes. 2009. Akupunktur Teori Meridian. Jakarta: Penerbit Akupunktur Indonesia
Terapi akupunktur ini dapat dijadikan sebagai terapi alternatif tambahan atau komplomenter selain dengan terapi pengobatan dalam mengatasi masalah tekanan darah pada lansia.

\section{Bagi Peneliti}

Penelitian ini dapat dilanjutkan dengan mengembangkan ilmu akupunktur sebagai terapi alternatif dalam upanya meningkatkan derajat kesehatan.

\section{KEPUSTAKAAN}

9 Nursalam. 2011. Konsep \& Penerapan Metodologi Penelitian Ilmu Keperawatan Pedoman Skripsi, Tesis dan Instrumen Penelitian Keperawatan. Jakarta: Salemba Medika

${ }^{10}$ Buckwalter. 2007. Buku Ajar Keperawatan Gerontik. Jakarta: Penerbit Buku Kedokteran: EGC.

${ }^{11}$ Ritujain. 2011. Pengobatan Alternative untuk Mengatasi Tekanan Darah. Jakarta: Gramedia Pustaka Utama.

12 Pearce, Evelyn c. 2007. Anatomi dan Fisiologi untuk Paramedic. Jakarta: Gramedia

13 Susalit, E, Dkk. 2001. Hipertensi Primer Dalam Buku Ajar Ilmu Dalam. Jilid II. Edisi Ketiga. Jakarta : FKUI.

14 Yin, Ganglin dan Zhenghua Liu. 2000. Advanced Modern Chinese Acupuncture Therapy. China: New World Press

${ }^{15}$ Suhariningsih. 2004. Pedoman Penggunaan Elektrostimulator dan Laser pada Terapi Akupunktur. Surabaya: Universitas Airlangga. 